\title{
Experimental Measurement of Moisture Sorption Isotherms and Isosteric Heat of Palm Hearts (Jomare) Harvested in the Algerian Sahara
}

\author{
Ahmed Amine Larbi ${ }^{1 *}$, Akil Loumani ${ }^{1}$, Ahmed Mediani ${ }^{1}$, Said Bennaceur ${ }^{2}$, Cherif Tigani ${ }^{1}$ \\ ${ }^{1}$ Unité de Recherche en Energies renouvelables en Milieu Saharien, URERMS, Centre de Développement des Energies \\ Renouvelables, CDER, Adrar 01000, Alegria \\ ${ }^{2}$ Laboratoire d'Energetique en Zones Arides, Université de Béchar, 08000, Algeria
}

Corresponding Author Email: aminelarbi@hotmail.fr

https://doi.org/10.18280/i2m.180310

Received: 5 March 2019

Accepted: 20 May 2019

\section{Keywords:}

solar dryer, palm heart, modelling,

hygroscopic, isosteric desorption heats

\begin{abstract}
Mastering the process of drying the palm heart (Jomare) requires knowing their isothermal sorption. The purpose of this work is the experimental determination of the palm heart sorption isotherms. the gravemitric method of saturated saline solutions is used at three different temperatures $\left(40,50\right.$ and $60{ }^{\circ} \mathrm{C}$ ) with a water activity extending from 0.067 to 0.85 . The equilibrium was obtained after about 10 days. Four mathematical models have been used (LANGMUIR, GAB, modified BET and Peleg) to model and predict hygroscopic behavior during drying and storage. After smoothing and optimization of these models on the basis of the statistical processing of the obtained data, the results shows that the GAB and modified BET models best match the sorption isotherms. The isosteric desorption heats for the heart of palm are calculated using the Clausius-Clapeyron equation. Through this study, an expression has been proposed that allow the prediction of the thermodynamic properties of the palm heart. The results of this research can be used to determine characteristic drying curves and to have optimal storage conditions.
\end{abstract}

\section{INTRODUCTION}

The significance of wild plants in subsistence farming in the world considered as a food supplement and as a means of survival during times of drought. The utilization of wild plants appears to be more typical and across the board in food insecure regions where an extensive variety of species groups are expended. The Saharian people know about the significance and contributions of wild plants to their day by day consume fewer calories. Wild plant species keep on providing essential vitality and micronutrient needs amid dry spell and social and political turmoil [1]. Compositional information of these plant materials could help in creating technological procedures to make the plant material eatable and more absorbable.

For human use, palms are considered among the most important plant family and ranked at the third position [2]. Various consumable items are acquired from palms, including the date palm fruits products, coconut palm nuts, and different palm oils. Some lesser/underutilized known consumable palm item is palm "Cabbage" or "Palm heart". Albeit most palm items are not accessible industrially, Palm hearts is a noteworthy piece of sustenance industry in Europe and America.

In Africa or more precisely in Algeria, heart of palm is a very widespread species in the south of Algeria. It is located in the central part of the trunk of palms, of whitish color. Several species distinguish from the exploitation way (wild or cultivated).

For several years, little effort has been devoted to the study of palm hearts. Tabora et al. [3] emphasize the use of the palm heart as a vegetable. Tabora chose the three big palms that feed the international palm heart market of the year 1990 to show their economic importance. Salvi et al. [1] considered palm heart as alternative source for human diet and the chemical analyzes of palm heart of Phoenix sylvestris shows the existence of important mineral and vitamin in particular the carbohydrate, crude protein, crude lipid, crude fiber, vitamin $\mathrm{B}$ complex, vitamin $\mathrm{C}$, vitamin $\mathrm{K}$, energy and minerals when compared with other commonly consumed. Sylvester et al. [4] has carried out a study on the illegal harvest (consumption and extraction modes) of the palm heart (Geonoma edulis) in the national parks of Costa Rica and concluded with some notion for the protection of the forests of the illegal harvest. Galletti [5] also talked about this illegal trade but in Brazil. The distinction between different species occurs mainly in their method of exploitation (wild or cultivated). There are several standards in the world that determine the codes of practice of of exploitation of the palm heart. The French standard CCP [6] is a norm intended only for wild palms

As vegetables and medicinal herbs are products that do not last long (perishable), their quality depends on several phenomena; harvesting, handling, transportation, storage and marketing [7]. An appropriate examination of these parameters may influence the production of microorganisms [8]. In this way, drying should assume a critical job for the preservation of these items and guarantees their economic and microbiological practicality.

Sorption isotherms are essential parameters for drying and cannot be predicted by theory but must be experimentally established. The sorption isotherm curves give information on the distribution and binding intensity of water molecules [9] as well as their functional availability in biochemical and biological substances. they also provide reliable data on the 
fluid balance of the product to know its stability range after drying, the sorption isotherms curves provide information to ensure better preservation during storage. This information relates to the optimum moisture content to be achieved during drying, which is close to steady state.

studies on sorption isotherms are carried out by mathematical modeling, eight mathematical models (in the literature) empirical and semi-empirical based on more or less physical bases [10], describing the correlation of water content with balance with the water activity of the products. among these models: GAB [11], modified BET [12], HendersonThompson [13], modified Halsey [14], modified Oswin [15], Peleg [16]. GAB is the most widely used model for various foods [17-20].

The experimental sorption curves are curves allowing determining the maximum temperature thresholds and the final water contents to serve to optimize the drying conditions of the different products so as to ensure the physicochemical and microbiological stability during the storage. The main focus of this paper is to determine these experimental curves for the palm heart at different temperatures at 30,40 and $50{ }^{\circ} \mathrm{C}$, and then use different mathematical models to model and predict hygroscopic behavior during drying and storage. The isosteric desorption heats are also presented and calculated by the Clausius-Clapeyron equation. Finally find the expression to predict the thermodynamic properties of the heart of the palm.

\section{MATERIALS AND METHODS}

\subsection{Simple preparation}

The research was carried out on young date palms "Gharsa" (see Figure 1) of the area of bouda in the south of Algeria "Adrar", under good conditions in the UREMS laboratory. After extracting the palm heart, preparing the samples for the study. The physico-chemical study leads to a composition shown in Table 1.

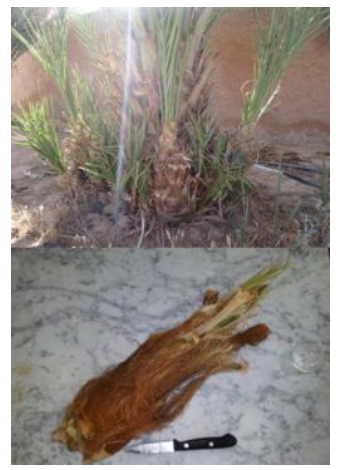

Figure 1. Young date palm "gharsa"

Table 1. Physico-chemical composition of the palm heart sample

\begin{tabular}{|c|c|c|c|c|}
\hline composition & Humidity & $\begin{array}{c}\text { Dry } \\
\text { matter }\end{array}$ & $\begin{array}{c}\text { Mineral } \\
\text { matter }\end{array}$ & $\begin{array}{c}\text { Organic } \\
\text { material }\end{array}$ \\
\hline$\%$ & 83 & 17 & 13.77 & 3.23 \\
\hline
\end{tabular}

\subsection{Description of the experimental procedure}

The procedures for obtaining water sorption isotherms from agri-food products are described in detail by several authors $[21,22]$. These procedures include either dynamic methods where the sample is placed in a stream of gas, temperature and humidity held constant, without air agitation, or static procedures (adsorb or desorb) where the sample, is placed in enclosures containing solutions of saturated salts and maintained at constant temperature and relative humidity, until reaching thermodynamic equilibrium. To determine the desorption isotherms of the heart of palm; we used the gravimetric technique of which it is based on the saturated saline solution method. The equilibrium moisture content is calculated for temperatures of 30,40 and $50{ }^{\circ} \mathrm{C}$.

The experimental device used consists of an oven filled with six jars of saturated saline solutions $\left(\mathrm{KOH}, \mathrm{MgCl}_{2} 6 \mathrm{H}_{2} \mathrm{O}\right.$, $\mathrm{K}_{2} \mathrm{CO}_{3}, \mathrm{NaNO}_{3}, \mathrm{KCl}$ and $\mathrm{BaCl}_{2} 6 \mathrm{H}_{2} \mathrm{O}$ ) which make it possible to obtain a water activity of between 0.07 and 0.89 [23].

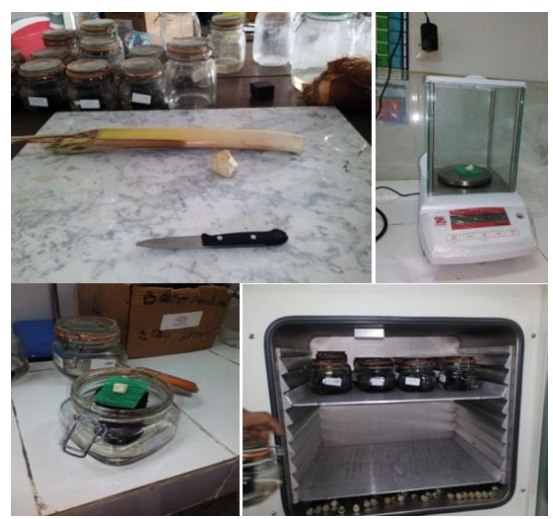

Figure 2. Sample preparation for the study of sorption isotherms

These solutions (see Table 2) are prepared by the desolation of a well-studied amount of salt in distilled water. The whole put at a higher temperature to ensure saturation and to arrive at equilibrium [7, 24]. All jars are made of half-liter glass with a tight-fitting lid. Each filled jar respects the ratio of $1 / 4$ saturated saline solution to vacuum. To confirm the saturation of solutions at equilibrium, a layer is kept visible from solid salts.

Each sample weighs $0.07 \pm 0.0001 \mathrm{~g}$. All the jars are placed in a tank where the temperature has been well controlled. This operation lasts until the temperature stabilization.

The next step is to put the samples that have been weighed before into pots that contain saturated saline solutions (see Figure 2). After the closing of the jars, the whole will be put in the same tank where the temperature was controlled. The weighing will be daily until the stabilization of the mass with an acceptable error of about $5 \%$.

$$
X_{e q}=\frac{m_{w}-m_{d}}{m_{d}} .100
$$

The moisture content of the hygroscopic equilibrium product Xeq is calculated by Eq. (1) where $m_{w}$ and $m_{d}$ are respectively the drying masses (before and after) [25].

\subsection{Statistical criteria of choice of models describing the sorption isotherms}

Eight mathematical models are found in the literature to model the sorption isotherms. These models are based on a 
more or less physical basis [26-28], which describes the relationship between equilibrium moisture content, equilibrium relative humidity and temperature.

Table 2. Standard values of the water activities of the salt solutions used

\begin{tabular}{|c|c|c|c|c|}
\hline \multicolumn{2}{|c|}{} & \multicolumn{3}{|c|}{ Water activity } \\
\hline Salt & $\begin{array}{c}A_{w} \\
=\varphi / 100\end{array}$ & $30^{\circ} \mathrm{C}$ & $40^{\circ} \mathrm{C}$ & $50^{\circ} \mathrm{C}$ \\
\hline KOH & 20 & 0.115 & 0.175 & 0.067 \\
\hline K2 $_{2} \mathbf{C O}_{3}$ & 47.7 & 0.181 & 0.196 & 0.144 \\
\hline KF & 74 & 0.333 & 0.295 & 0.312 \\
\hline NACL & 79 & 0.352 & 0.39 & 0.392 \\
\hline KCL & 84.5 & 0.616 & 0.634 & 0.539 \\
\hline KI & 85 & 0.635 & 0.668 & 0.576 \\
\hline
\end{tabular}

Table 3. Mathematical models used to describe sorption isotherms

\begin{tabular}{|c|c|}
\hline Models names & Models equations \\
\hline $\begin{array}{c}\text { GAB (van den } \\
\text { berg 1984) [29] }\end{array}$ & $X_{e q}=\frac{A \cdot B \cdot C \cdot A_{w}}{\left[1-B \cdot A_{w}\right] \cdot\left[1+B \cdot A_{w}+B \cdot C \cdot A_{w}\right]}$ \\
\hline $\begin{array}{c}\text { BET modified } \\
\text { Iglesias and } \\
\text { chirifie1982) } \\
{[30]}\end{array}$ & $X_{e q}=\frac{(A+B T) \cdot C \cdot A_{w}}{\left[1-A_{w}\right] \cdot\left[1-A_{w}+C \cdot A_{w}\right]}$ \\
\hline $\begin{array}{c}\text { Peleg model } \\
\text { (1993) [16] }\end{array}$ & $X_{e q}=A \cdot A_{w}^{K 1}+B \cdot A_{w}^{K 2}$ \\
\hline $\begin{array}{c}\text { Langmuir (1916) } \\
{[31]}\end{array}$ & $X_{e q}=\frac{1}{\left[A+B \cdot A_{w}^{c-1}\right]}$ \\
\hline
\end{tabular}

In this work, we have studied in detail four mathematical models which have been grouped together in Table 3 for the adjustment and modeling of hearts palm sorption isotherms for the three temperatures 30,40 and $50{ }^{\circ} \mathrm{C}$.

The analysis of the fit and choice of the appropriate model for estimating the model constants from the experimental results is done via two software packages (curve Expert 1.4 and Origin 6). Three statistical parameters for calculating the gap are defined by Eqns. 2, 3 and 4. The correlation coefficient $(\mathrm{r})$, the standard error $(\mathrm{S})$ and the mean relative difference percentage $(\mathrm{P})$.

$$
S=\sqrt{\frac{\sum_{i=1}^{n_{\text {exp.data }}}\left(X_{e i}-X_{e_{c a l}}\right)}{n_{\text {exp data }}-n_{\text {param }}}}
$$

$$
\begin{gathered}
r=\sqrt{1-\frac{\sum_{i=1}^{n_{\text {exp.data }}}\left(X_{e i}-X_{e_{c a l}}\right)^{2}}{\sum_{i=1}^{n_{\text {exp.data }}}\left(X_{e}-X_{e i}\right)^{2}}} \\
P \%=\frac{100}{n} \sum_{i=1}^{n_{\text {exp.data }}\left(\frac{X_{e_{c a l i}}-X_{e i}}{X_{e i}}\right)}
\end{gathered}
$$

$\mathrm{Xe}_{\mathrm{cali}}$ and $X \mathrm{e} i$ are respectively the calculated and the experimental value of equilibrium moisture content, $n_{\text {param }}$ is the parameters number of the particular model.

\subsection{Determination of the isosteric heat of sorption}

The isosteric heat of sorption is the energy on fixing the water to the substrate, or else additional heat to the heat of vaporization of the pure water that would have to be supplied with the product to dehydrate it, can be determined by an equation derived from the Clausius-Clapeyron equation [18, 32,33 ], from the moisture sorption data.

$$
Q_{s t}=-R\left[\frac{\partial\left(\ln A_{w}\right)}{\partial \frac{1}{T}}\right]
$$

Assumed that the isosteric heat of sorption independent of temperature, the integration of this equation gives equation (6):

$$
\ln \left(a_{w}\right)=-\left(\frac{q_{s t}}{R}\right)\left(\frac{1}{T_{k}}\right)+k
$$

\section{RESULTS AND DISCUSSION}

The experimental desorption isotherms obtained at 30, 40 and $50{ }^{\circ} \mathrm{C}$ are presented in Figure 3 . They have a sigmoidal appearance according to the classification of BET, and in a concordance with the behavior of other agri-food products [34]. It is noted that the equilibrium water content increases with the increase in the activity of the water they contain. A bending region observed on sorption isotherms in the range of water activity of 65-80.

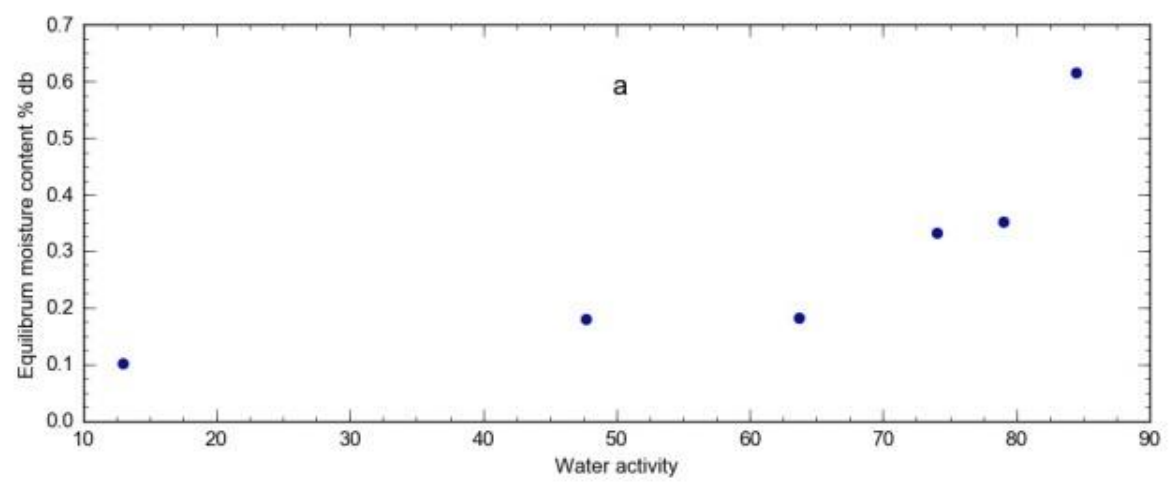



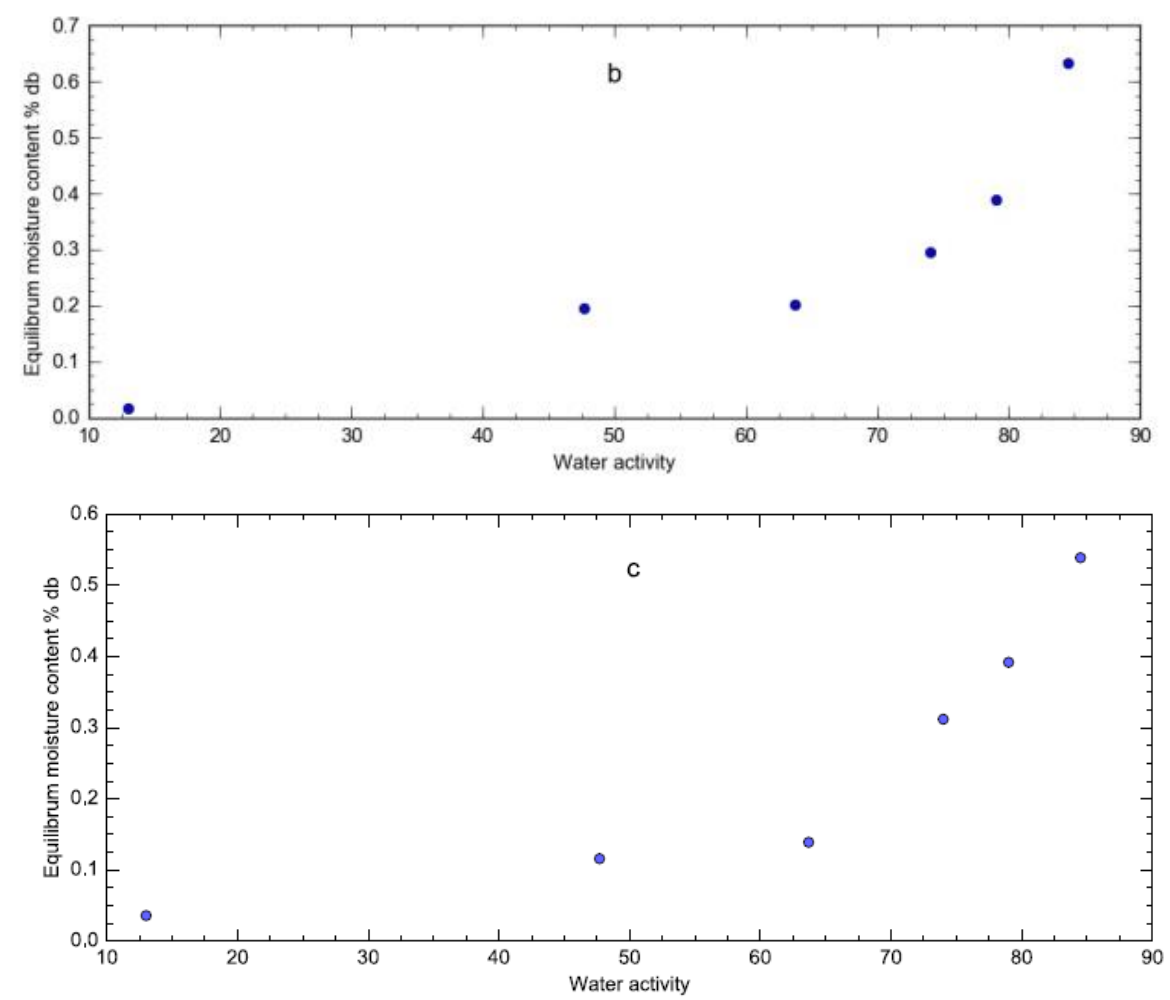

Figure 3. desorption isotherms of heart of palm at 30 (a), 40 (b) and $50{ }^{\circ} \mathrm{C}$ (c)

According to the lutirature and according to [7, 35], the curves of the sorption isotherms of palm tree can be divided into three zones:

$>$ The first zone of the water activity in the range of (1350 ) is a zone of a minimal amount of water. This quantity is due to the active sites by the hydrogen bonds in the molecules of the polar groups

The second zone (50-85) is the zone of chemical and biochemical reactions. Under the monolayer is a small amount of water and at a given moment when we have high moisture content the water fills the micropores and macropores.

$>$ The third zone (70 to 0.9 ) where the excess of water in the macrocapillaries causes the creation or the microbial birth.

Table 3 shows the results of the non-linear regression analysis of the palm heart desorption isotherms obtained at 30, 40 and $50{ }^{\circ} \mathrm{C}$. The values of the constants of the models are all included in the table 4 . A, B and C are the standard coefficients of each model. $\mathrm{r}$ and EST are respectively the correlation coefficient and the standard error.

Table 4. Results of the adjustment of the sorption isotherms

\begin{tabular}{|c|c|c|c|c|c|c|c|}
\hline Models names & $\mathrm{T}\left({ }^{\circ} \mathrm{C}\right)$ & $\mathrm{A}$ & $\mathrm{B}$ & $\mathrm{C}$ & $\mathrm{R}$ & $\mathrm{R}^{2}$ & EST \\
\hline \multirow{3}{*}{$\mathrm{GAB}$} & 30 & -6.447 & 2.81 & 9.996 & 0.983 & 0.967 & 0.042 \\
& 40 & -1.027 & 3.357 & 9.708 & 0.853 & 0.728 & 0.035 \\
& 50 & -6.466 & 1.105 & 9.990 & 0.985 & 0.971 & 0.034 \\
\hline \multirow{2}{*}{ Modified } & 30 & -6.931 & - & 9.894 & 0.984 & 0.969 & 0.035 \\
$\mathrm{BET}$ & 40 & -1.217 & - & 9.90 & 0.831 & 0.690 & 0.113 \\
& 50 & -6.386 & - & 9.895 & 0.985 & 0.971 & 0.031 \\
\hline \multirow{3}{*}{ Peleg } & 30 & 1.107 & 5.510 & - & 0.885 & 0.783 & 0.235 \\
& 40 & 2.209 & 4.532 & - & 0.861 & 0.741 & 0.122 \\
& 50 & 2.617 & 1.588 & - & 0.971 & 0.934 & 0.254 \\
\hline \multirow{3}{*}{ langumier } & 30 & 1.393 & -3.919 & 1.276 & 0.986 & 0.973 & 0.038 \\
& 40 & -1.110 & 1.325 & -3.408 & 0.784 & 0.614 & 0.137 \\
& 50 & 1.815 & -3.300 & 8.651 & 0.985 & 0.971 & 0.234 \\
\hline
\end{tabular}

Figures 4 and 5 show the experimental adsorption of the palm hearts at 30 (a), 40 (b) and $50{ }^{\circ} \mathrm{C}$ (c) simulated respectively by GAB and BET models. The processing of the obtained data showed us acceptable results for the prediction of the moisture content of the palm heart. The results provided by the two GAB and Peleg models show a good match with the sorption isotherms compared with the other models (low standard error and high correlation coefficient).

\section{Determination of Isosteric Heat of Sorption:}

Using Clausius-Clapeyron Eq. 6, the isosteric isotherms of palm core sorption are plotted against $\ln (\mathrm{aw})$ versus $(1 / \mathrm{Tk})$ for fixed equilibrium content values. The net isosteric heat of sorption can be calculated at each value of equilibrium moisture content from the slope of the isosteric curves which is equal to (- (qst / R)). 

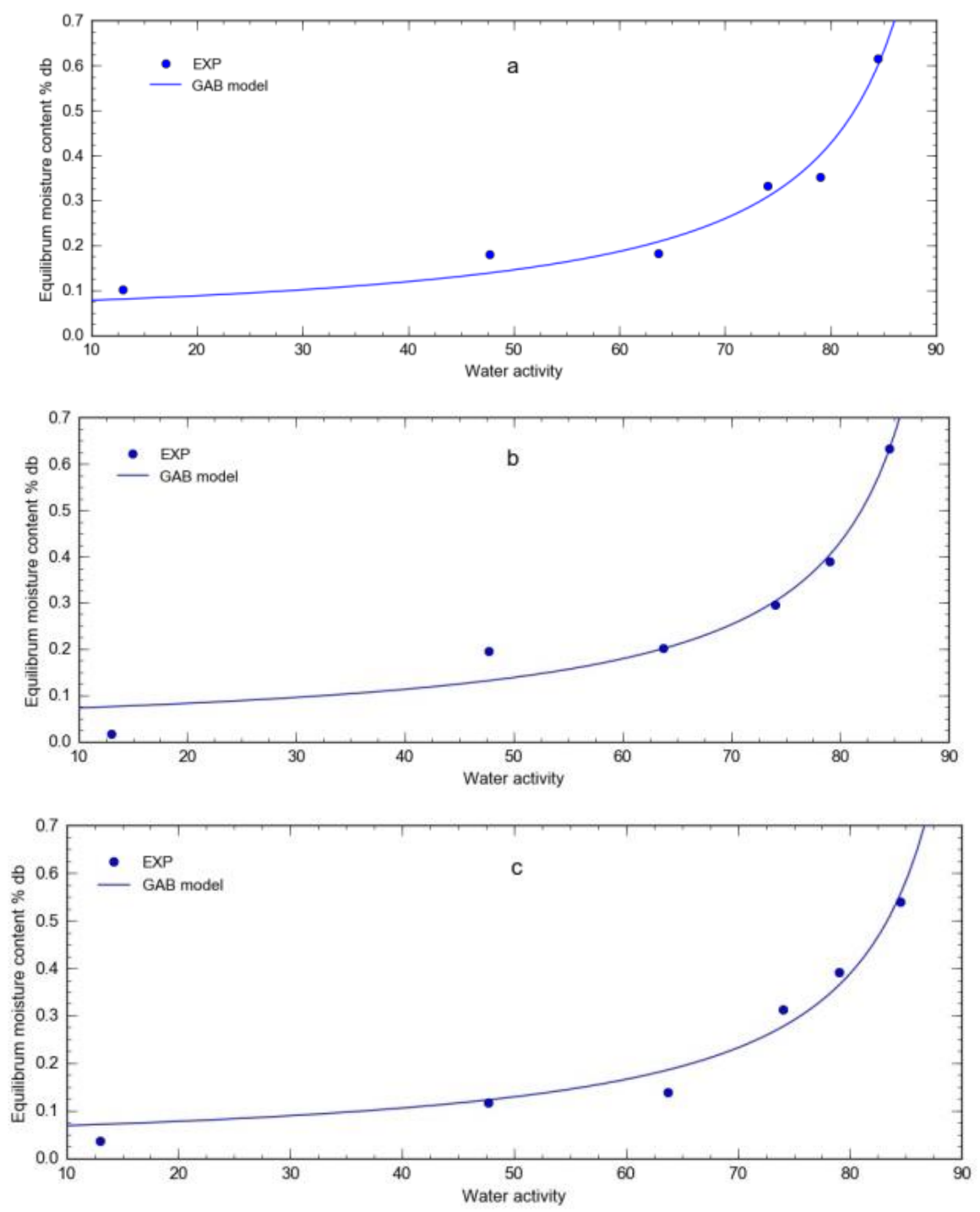

Figure 4. Experimental adsorption isotherms of heart of palm at 30 (a), 40 (b) and $50{ }^{\circ} \mathrm{C}$ (c) simulated by the GAB model
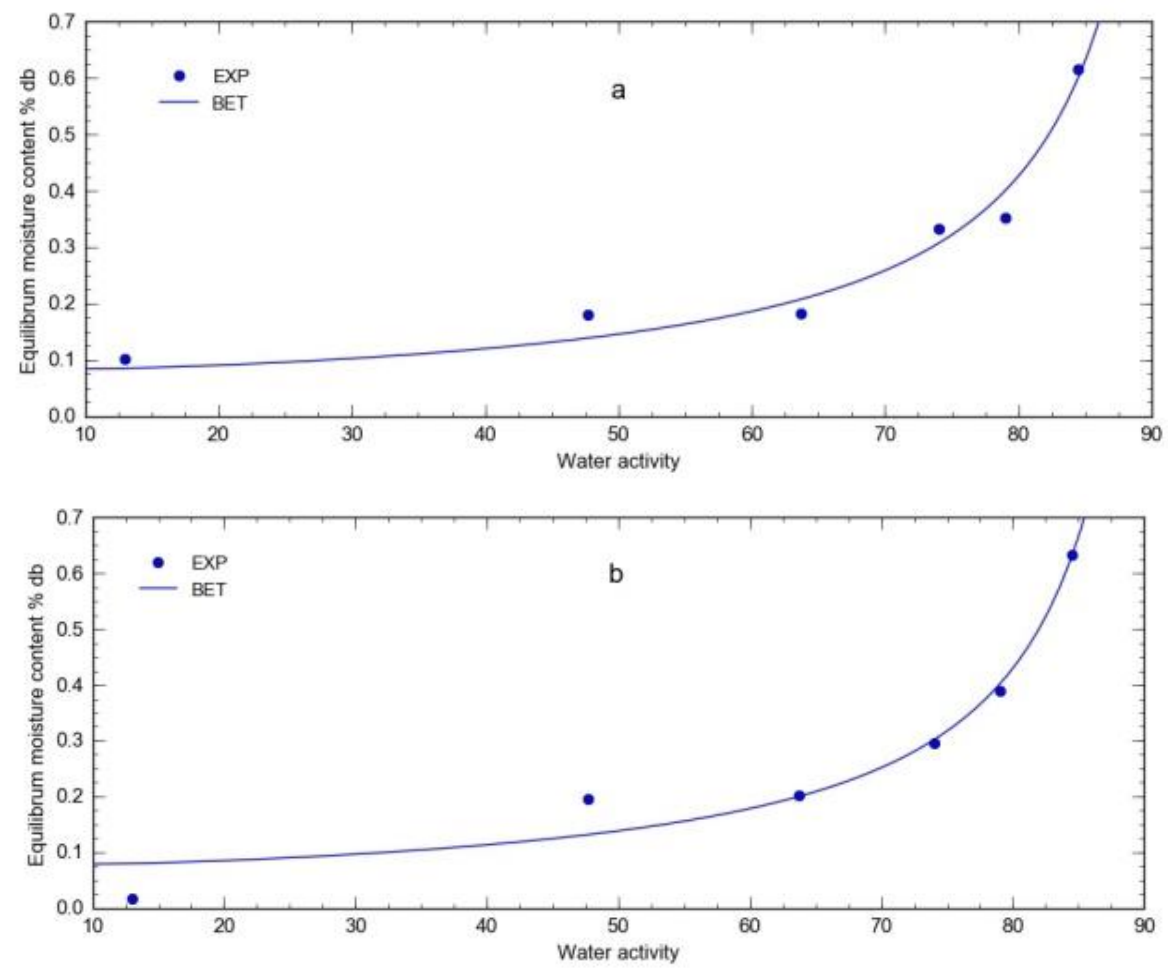


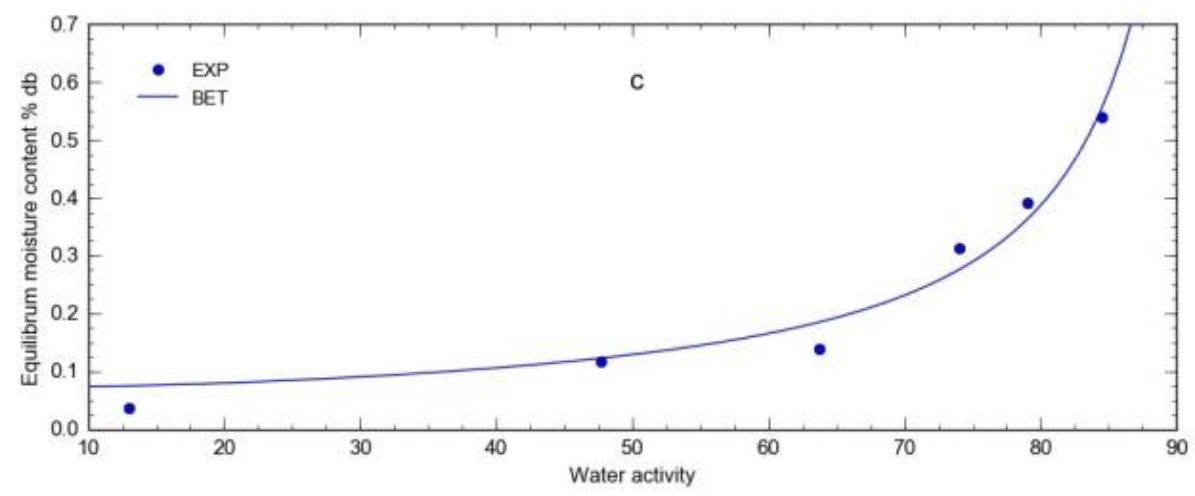

Figure 5. Experimental adsorption isotherms of heart of palm at 30 (a), 40 (b) and $50{ }^{\circ} \mathrm{C}$ (c) simulated by the BET model

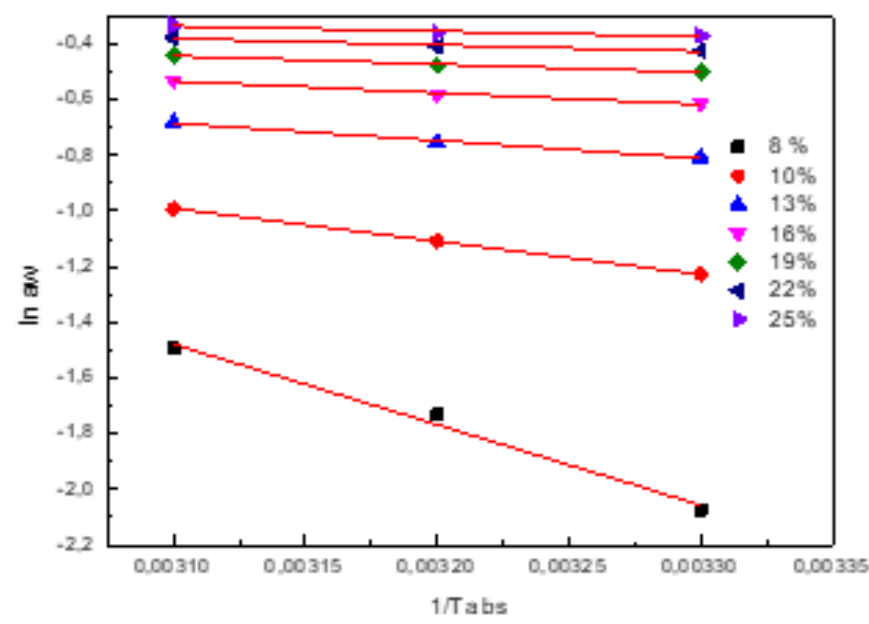

Figure 6. Curves of desorption isosteres for the palm heart
The isosteric curves determined for the palm heart using the Clausius-Clapeyron equation are shown in Figure 6. We have the same remark that [19] concerning the increase in the moisture content of palm heart causes a decrease towards zero absolute values of slopes

The isosteric net sorption heats obtained for different equilibrium water contents were determined using the GAB model in combination with the Eq. 2. The variations of the palm hearts desorption with the water content are shown in Figure 7. They show that isosteric heat is more important at low water content, illustrating the strong bond of water to the substrate, and it becomes negligible in the presence of latent heat at high humidity. The following function used to describe the relationship between isosteric sorption heat and equilibrium water content:

$$
q_{s t}=\frac{1}{-2.355569+3.576252 X_{e q}-1.400303 X_{e q}^{2}}
$$

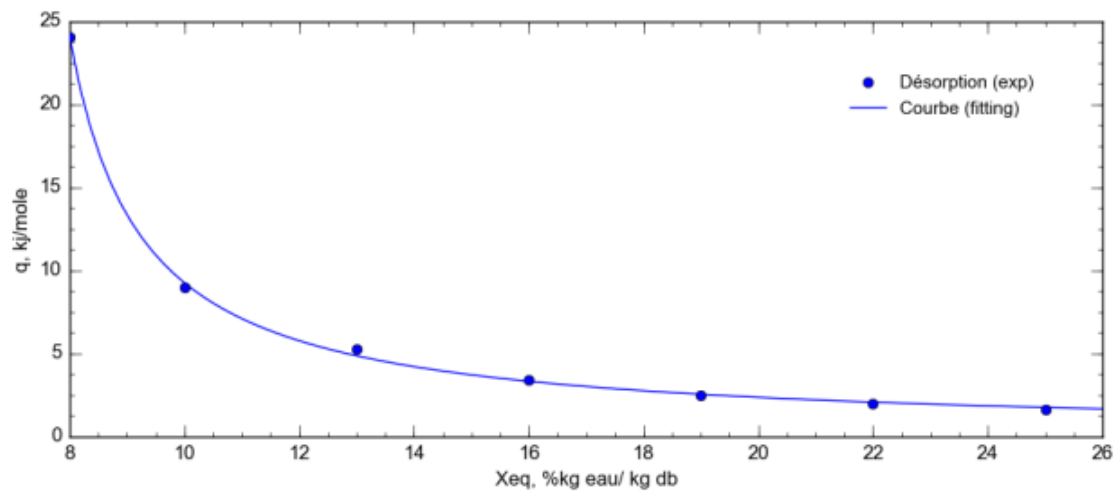

Figure 7. Isosteric desorption heat as a function of equilibrium water content for the palm heart

\section{CONCLUSIONS}

The experimental sorption curves have made it possible to determine the maximum temperature thresholds and the final water contents which serve to optimize the drying conditions of the different products, so as to ensure physicochemical and microbiological stability during storage. The curves of the palm heart sorption isotherms were determined experimentally by the static gravimetric method for three temperatures $(30,40$ and $\left.50{ }^{\circ} \mathrm{C}\right)$. The experimental results of the palm heart are shown by the sorption isotherms by the three temperatures $(40$, 50 and $60{ }^{\circ} \mathrm{C}$ ). These sorption curves are adjusted by four statistical models. The analysis of the statistical parameters shows that the GAB and BET models are the best that describe the set of sorption isotherms and which better represents the relationship between the three parameters; equilibrium water content, water activity and temperature. The net heat of isosteric sorption of palm heart is calculated.

\section{REFERENCES}

[1] Salvi, S.S., Katewa, J. (2014). Preliminary assessment of nutritional value of palm heart of Phoenix sylvestris (Roxb). Int. Food Res. J., 21(5): 2051-2054.

[2] Johnson, D.V. (1995). Palm conservation: Its antecedents, 
status and needs. World Palm Symp. Fairchild Trop. Bot. Gard.

[3] Tabora, P.C., Balick, M.J., Bovi, M.L.A., Guerra, M.P. (1993). Hearts of palm (Bactris, Euterpe and others). Pulses and Vegetables, Chapman and Hall, London, pp. 193-218.

[4] Ylvester, O.L.S., Valos, G.E.A., De Biología, E., Rica, U.D.C., Pedro, S., José, S., Rica, C. (2009). Illegal Palm Heart ( Geonoma edulis ) Harvest in Costa Rican National Parks : Patterns of Consumption and Extraction 1. Economic Botany, 63: 179-189.

[5] Galleti, F.C.M. (1998). Palm heart harvesting in the Brazilian Atlantic forest ] changes in industry structure and the illegal trade. J. Appl. Ecol., 35: 294-301.

[6] Moussa, F., Kahn, F. (1997). Trois palmiers pour trois capitales amazoniennes. Bulletin de l'Institut Français d'études Andines, 26(1).

[7] Bennaceur, S., Draoui, B., Touati, B., Benseddik, A., Saad, A., Bennamoun, L., Renouvelables, E. (2015). Determination of the moisture-sorption isotherms and isosteric heat of henna leaves. Journal of Engineering Physics and Thermophysics, 88(1): 53-62. https://doi.org/10.1007/s10891-015-1167-9

[8] Wilson, L., Wismiewski, M.E., Biles, C.L., MacLaughlin, R., Chalutz, E. (1991). Biological control of post-harvest diseases of fruits and vegetables. Altern. to Synth. Fungic. Crop Prot, 10: 172-177. https://doi.org/10.1146/annurev.py.27.090189.002233

[9] Mitrevsky. V. (1973). Mathematical modelling of the sorption isotherms of quince. Mathematical Modelling of the Sorption Isotherms of Quince, 21(5): 13-25. https://doi.org/10.2298/TSCI170118095M

[10] Kiranoudis, E.T., Kiranoudis, D.M.K.C.T., Maroulis, Z.B. (1993). Equilibrium moisture content and heat of desorption of some vegetables. Journal of Food Engineering, $\quad 20(1)$ : $\quad 55-74$ https://doi.org/10.1016/0260-8774(93)90019-G

[11] Van den Berg, C. (1984). Description of water activity of food engineering purposes by means of the GAB model of sorption. Engineering science in the food industry, 311-321

[12] Iglesias, H.A., Chirife, J. (1982). Handbook of Food Isotherms: Water Parameters for Food and Food Components. Acad. Press Inc., New York, pp. 262-283.

[13] Stakić, M.B. (1997). Mathematical modelling and simulation of corn drying in a fixed bed. IFAC Proceedings $\quad$ Volumes., 30: 119-124. https://doi.org/10.1016/S1474-6670(17)44419-3

[14] Henderson, S.M. (1952). A basic concept of equilibrium moisture content. Agric. Eng., 33(1): 29-31.

[15] Oswin, C.R. (1946) The kinetics of package life III, the isotherm. Journal of the Society of Chemical Industry, 65: 419-421. http://dx.doi.org/10.1002/jctb.5000651216

[16] Peleg, M. (1993). Assessment of semi-empirical four parameter general model for sigmoid sorption isotherms. J. Food Process. Eng., 16(1): 21-37. https://doi.org/10.1111/j.1745-4530.1993.tb00160.x

[17] Simal, S., Fermenia, A., Cstell-Palou, A. (2007). Water desorption thermodynamic properties of pineapple. J. Food Eng., $\quad 80$ : 1293-1301. https://doi.org/10.1016/j.jfoodeng.2006.10.001

[18] Jamali, A., Kouhila, M., Mohamed, L.A., Idlimam, A., Lamharrar, A. (2006). Moisture adsorption - desorption isotherms of Citrus reticulata leaves at three temperatures.
Journal of Food Engineering, 77(1): $71-78$. https://doi.org/10.1016/j.jfoodeng.2005.06.045

[19] Machhour, H., Idlimam, A., Mahrouz, M., El Hadrami, I., Kouhila, M. (2012). Sorption isotherms and thermodynamic properties of peppermint tea ( Mentha piperita ) after thermal and biochemical treatment. Journal of Materials and Environmental Science, 3(2): 232-247.

[20] Idlimam, A., Lamharrar, A., Koukouch, A., Kouhila, M., Asbik, M. (2014). Study of Solar Drying Process and Moisture Desorption Isotherm of Moroccan zygophyllum gaetulum by Forced Convection. 5: 139146.

[21] Pini, R., Ottiger, S., Rajendran, A., Storti, G., Mazzotti, M. (2006). Reliable measurement of near-critical adsorption by gravimetric method. Adsorption, 12(5-6): 393-403. https://doi.org/10.1007/s10450-006-0567-8

[22] Placet, V., Passard, J., Perré, P. (2008). WAVE T*, a custom device able to measure viscoelastic properties of wood under water-saturated conditions (* WAVE T: Environmental Vibration Analyser for Wood). Maderas. Ciencia y Tecnología, 10(1): 45-60.

[23] Arslan, N., Tog, H. (2006). The fitting of various models to water sorption isotherms of tea stored in a chamber under controlled temperature and humidity. Journal of Stored Products Research, 42: 112-135. https://doi.org/10.1016/j.jspr.2005.01.001

[24] Kouhila, M., Kechaou, N., Otmani, M. (2002). Experimental study of sorption isotherms and drying kinetics of moroccan eucalyptus globulus. Drying Technology An International Journal, 2027-2039. https://doi.org/10.1081/DRT-120015582

[25] Medina, E.D., Rodríguez, E.R., Romero, C.D. (2007). Chemical characterization of Opuntia dillenii and Opuntia ficus indica fruits. Food chemistry, 103(1): 3845.

[26] Idlimam, N.A.A., Lamharrar, A. (2008). Thermodynamic properties and moisture sorption isotherms of agrania spinosa and zygophyllum geatulum. J. Agron., 7(1): 1-14.

[27] Lahsasni, S., Kouhila, M., Mahrouz, M. (2004). Adsorption - desorption isotherms and heat of sorption of prickly pear fruit (Opuntia ficus indica). Energy Conversion and Management, 45: 249-261. https://doi.org/10.1016/S0196-8904(03)00133-X

[28] Kouhila, M., Belghit, A., Daguenet, M., Boutaleb, B.C. (2001). Experimental determination of the sorption isotherms of mint (Mentha viridis), sage (Salvia offcinalis) and verbena (Lippia citriodora). Journal of Food Engineering, 47(4): 281-287. https://doi.org/10.1016/s0260-8774(00)00130-8

[29] Maroulis, Z.B., Tsami, E. (1984). Application of the GAB model to the moisture sorption isotherms for dried fruits. Jour. Foods, Eng , Elsevier, 7(1): 63-78. https://doi.org/10.1016/0260-8774(88)90069-6

[30] Iglesias, H.A., Chirifem J. (1982). Water sorption parameters for food and food components. Handbook of Food Isotherms: Water Sorption Parameters for Food and Food Components, Acad. Press. https://doi.org/10.1016/b978-0-12-370380-4.x5001-4

[31] Thommes, M., Findenegg, G.H., Schoen, M. (1995). Critical depletion of a pure fluid in controlled-pore glass. Experimental results and grand canonical ensemble Monte Carlo simulation. Langmuir, 11(6): 2137-2142. 
[32] Labuza, T.P., Kaanane, A., Chen, J.Y. (1985). Effect of temperature on the moisture sorption isotherm and water activity shift of two dehydrates food. J. Food Sci., 50: 385-391. https://doi.org/10.1111/j.13652621.1985.tb13409.x

[33] Mohamed, L.A., Kouhila, M., Lahsasni, S., Jamali, A., Idlimam, A. (2005). Equilibrium moisture content and heat of sorption of Gelidium sesquipedale. Stored Prod. Res., 41:

199-209. https://doi.org/10.1016/j.jspr.2004.03.001

[34] Kapsalis, J.G. (1987). Influence of hysteresis and temperature on moisture sorption isotherms in Water Activity: Theory and Applications to Foods, LB Rokcland and LR Beuchat, Eds.

[35] Barbosa-Canovas, G.V., Fontana, A.J., Schmidt, S.J., Labuza, T.P. (2007). Water activity in foods. Fundamentals and Applications.

\section{NOMENCLATURE}

$\begin{array}{ll}\text { A,B,C,D model coefficients [-] } \\ \mathrm{a}_{\mathrm{w}} \quad \text { water activity (dimensionless) [-] } \\ \mathrm{K} & \text { constant [-] } \\ \mathrm{m}_{\mathrm{w}} & \text { mass of wet matter }[\mathrm{kg}] \\ \mathrm{m}_{\mathrm{d}} & \text { mass of dry matter [kg] } \\ n_{\text {exp.data }} & \text { number of experimental points [-] } \\ n_{\text {param }} & \text { number of parameters of the particular model [-] } \\ \mathrm{P} & \text { percent average relative deviation [-] } \\ \mathrm{q}_{\mathrm{st}} & \text { net isosteric heat of desorption }[\mathrm{J} / \mathrm{mol}] \\ \mathrm{R} & \text { universal gas constant }[\mathrm{kJ} / \mathrm{mol} . \mathrm{K}] \\ \mathrm{r} & \text { correlation coefficient }[-] \\ \mathrm{S} & \text { standard error [-] } \\ \mathrm{T} & \left.\text { temperature [ }{ }^{\circ} \mathrm{C}\right] \\ \mathrm{T}_{\mathrm{k}} & \text { the absolute temperature }[\mathrm{K}] \\ \mathrm{X} \mathrm{e}_{\text {cali }} & \text { ith predicted moisture content }[\mathrm{kg} / \mathrm{kg} \% \mathrm{~d} . \mathrm{b}] \\ X \mathrm{e} i & \text { ith experiment moisture content }[\mathrm{kg} / \mathrm{kg} \% \mathrm{~d} . \mathrm{b}] \\ X & \text { equilibrium moisture content }[\mathrm{kg} / \mathrm{kg}]\end{array}$

